Reflection

1 David Harvey, "The Right to the City," New Left Review 53 (2008): 23.

2 Carl DiSalvo, "Design, Democracy and Agonistic Pluralism," paper presented at Design Research Society Conference, Montreal, July 7-9, 2010.

3 Colleagues also contributing to the ASF-UK Change by Design methodology examined in this paper include Beatrice De Carli, Matthew Anthony French, Melissa Kinnear, Isis Nuñez Ferrera, and Naomi Shinkins. The implementation of the Change by Design workshops have been supported by The Bartlett Development Planning Unit of University College London, the Scarcity and Creativity in the Built Environment project led by University of Westminster and Sheffield School of Architecture of University of Sheffield.

4 For the former, see Peter Blundell Jones, Doina Petrescu, and Jeremy Till, eds., Architecture and Participation (London: Spon Press, 2005); Markus Miessen and Shumon Basar, Did Someone Say Participate? An Atlas of Spatial Practice (Frankfurt am Main: Revolver, 2006); and Paul Jenkins and Leslie Forsyth, Architecture, Participation and Society (London: Routledge, 2010). For the latter, see Erling Björgvinsson, Pelle Ehn, and PerAnders Hillgren, "Agonistic Participatory Design: Working with Marginalised Social Movements," CoDesign: International Journal of CoCreation in Design and the Arts 8, no. 203 (2012): 127-44; and Carl DiSalvo, Adversarial Design (Cambridge, MA: The MIT Press, 2012).

\section{Re-imagining Participatory Design: Reflecting on the ASF-UK Change by Design Methodology Alexandre Apsan Frediani}

\section{Introduction}

The thinking and practice of participatory design in processes of urban development and informal settlement upgrading has been associated with a variety of agendas and purposes. Sometimes it has been used as a mechanism of "inclusion" for a predefined vision and ideal of the city, and at other times it has been used as a means to expand the "collective power to reshape the processes of urbanization." ${ }^{1}$ Similar discussions have taken place in debates around the links between democracy and design, in which design has sometimes been approached as a means of improving or enabling structures of governance and at other times of opening up new spaces for contestation and trajectories for social change. ${ }^{2}$

Through the Architecture Sans Frontières-UK (ASF-UK) Change by Design workshops, I have been working with colleagues and supporting institutions to build on the latter trends in the field of participatory design, in which participation in informal settlement upgrading processes is part of a wider agenda of deepening democratic practices in the city. ${ }^{3}$ Through engagements with collectives that are struggling for the rights of informal settlement dwellers in Salvador da Bahia (Brazil), Nairobi (Kenya), and Quito (Ecuador), we have been reflecting on the role of participatory design in the production of a more just city, not only questioning unequal distribution of resources and exploitative relations, but also as a practice that opens up spaces for new imaginaries about the city, citizenship, and transformation.

This article aims to reflect on the ASF-UK Change by Design methodology in participatory informal settlement upgrading, positioning it within ongoing debates about the conceptualization and practice of participatory design. The first part of this article draws on key literature exploring the relationship between participation and architecture and participation and design to identify the trends in the field of participatory design, ${ }^{4}$ especially those relevant to informal settlement upgrading. These 
5 Rod Burgess, "Self-Help Housing Advocacy: A Curious Form of Radicalism: A Critique of the Work of John F. C. Turner," in Self-Help Housing, ed. Peter M. Ward (London: Mansell Publishing Limited, 1982), 56-97.

6 See, for example, Cynthia E. Smith, Design for the Other 90\%: Cities (New York: Cooper-Hewitt, National Design Museum, 2011)

7 Fran Tonkiss, Cities By Design: The Social Life of Urban Form (Cambridge, UK: Polity, 2013). trends are explored through their preoccupations with form/product, use, governance, and meaning. The article then identifies tensions in the conceptualization and practice of participatory design that have been particularly relevant to the elaboration of the Change by Design methodology. The second part of this article elaborates on key reflections emerging from the participatory design experience undertaken through the ASF-UK Change by Design workshops. These reflections serve as a potential conceptual lens to inform the positioning of participatory design practices in debates on the production of just cities from a critical urban theory perspective.

\section{Trends in Participatory Design}

John Turner's critique of centralized and top-down production of housing in the 1970s made particular reference to the form of housing estates, which were unresponsive to the processes of construction taking place in informal settlements in Peru at the time. Self-help was supported by Turner as a mechanism to produce an urban form that would be more adequate because it would allow for incremental upgrading by local residents and also let the urban poor remain in well-located areas in the city. Turner's work served as an inspiration to many architects and urban planners, who saw the potential of using their expertise to support households in improving the built environment in which they lived, recognizing local knowledge and priorities. Although they became a major reference in the struggle against the peripherization of the poor, Turner's ideas also faced criticism, especially from Burgess, who argued that self-help merely reproduced exclusionary market forces, rather than challenging them. ${ }^{5}$

In the field of design, tensions have emerged in the literature around the emphasis on the product of design as a means to alleviate poverty in informal settlements. In recent years we have seen a proliferation of design innovations focused on artifacts and systems that would be more responsive to the needs of informal settlement dwellers by potentially improving their access to information, services, and facilities. This has led to a variety of design products, from prototypes demonstrating innovative use of local resources (e.g., sand-bags or bamboo) to new mobile phone applications aimed at generating data about residents living in informal settlements. ${ }^{6}$ Although these initiatives often claim to be implemented through a collaborative engagement involving a variety of stakeholders, they have been criticized for not questioning the wider unequal power relations shaping the production of these artifacts and systems. ${ }^{7}$ Thus, critiques such as those from Burgess and Tonkiss have underscored the importance of engaging with the political economy shaping design processes and products. 
8 Marc Steen, "Human-Centered Design as a Fragile Encounter," Design Issues 28, no. 1 (Winter 2012): 72-80.

9 Michael J. Muller and Sarah Kuhn, "Participatory Design," Communications of the ACM 36, no. 6 (1993): 24-28.

10 Richard Buchanan, "Human Dignity and Human Rights: Thoughts on the Principles of Human-Centered Design," Design Issues 17, no. 3 (Summer 2001): 35-39.

11 Ibid., 37.

12 Ezio Manzini and Francesca Rizzo, “Small Projects/Large Changes: Participatory Design as an Open Participated Process," CoDesign 7, no. 3-4 (2011): 199-215.

13 Ibid., 213-14.
A second evolving trend in the field of participatory design refers to the use of design, and it is often associated with the processes of participation in the design of artifacts, as well as information and communication technologies. Sometimes referred as human-centered design, ${ }^{8}$ participation is practiced with the objective of improving communication in the process of design and generating not only responsive results, but also sustained results over time. Debate focuses on the relationship between the designer and the user, and the argument is that co-design has the potential to find solutions and possibilities that would not otherwise emerge if not for the exchange between the technical knowledge of the designer and the practical knowledge of the user. ${ }^{9}$ Ultimately, participation is justified as a means to enhance users' satisfaction with the product of design. Buchanan has highlighted that current trends of human-centered design have focused predominantly, and dangerously, on matters of sheer usability but have overlooked a deeper engagement with notions of human dignity..$^{10}$ Buchanan calls for a human-centered design that is understood as the "ongoing search for what can be done to support and strengthen the dignity of human beings as they act out their lives in varied social, economic, political, and cultural circumstances."11

These critiques of the practice of "human-centered design" are founded on a perspective similar to the underlying motivation that has informed the practices fostered by the Design for Social Innovation and Sustainability (DESIS) Network. While still focusing on the relationship between the designer and the user, Manzini and Rizzo's work takes on a more political character in its preoccupation with the "use" fostered by participatory design initiatives. ${ }^{12}$ Their work calls for citizen participation in design processes to advance new lifestyles and to question dominant market-oriented modes of production in society. Design devices are elaborated with great ingenuity and understood as tools of conversations and enablers of experiences:

Designers can be facilitators or mediators, but also triggers. They can operate as members of a co-design team, collaborating with a well-defined group of final users, or as design activists, launching socially meaningful design initiatives. In any case, designers play a specific role in conceiving and realizing a variety of design devices. In brief, the best they can do to promote citizens' participation in large-scale transformations is to use their creativity and their design knowledge and skills "to make things happen" and, in this way, to promote and sustain the social conversation on possible futures. ${ }^{13}$ 
Similar issues have been raised from an urban development perspective, which embeds the practice of participatory design into discussions around urban governance. ${ }^{14}$ Engaging criticisms that participatory design would be tackling merely the manifestations of urban poverty, rather than more fundamental issues associated with the mode of urban planning, this literature articulates the benefits and mechanisms by which communities could be better involved in the processes of managing and delivering urban services. For example, Sanoff defines participatory design as "an attitude about a force for change in the creation and management of environments for people." ${ }^{15}$ Meanwhile, Hamdi calls for participatory practices that build on existing potentials, strengthen community initiatives and organizations, and foster collaboration between governments and civil society groups. Rather than exhaustively exploring the product of design, Hamdi explores the process of design, understood as a means to generate collaboration and strengthen communities' abilities to bring about positive change.

Finally, a more coherent understanding of design and participation is emerging-one which recognizes design as the subject rather than object of community participation, not the result of the process, but the means to it. In this sense, design can be an effective means of community enablement-a process that will improve the efficiency of design practice, will assert design as a part of the body politic of housing, and at the same time will promote the architecture of cooperation. ${ }^{16}$

Drawing on the work of Otto Königsberger on action planning, Hamdi and Reinhard demonstrate how participation in design can foster local catalyst actions and set precedents for more democratic forms of urban governance. ${ }^{17}$ This trend in the field of participatory design in the context of urban governance resonates with the practices described by DiSalvo as "design for politics," which aim to improve the conditions within which democracy operates. DiSalvo expands:

14 See Nabeel Hamdi, Housing Without Houses: Participation, Flexibility, Enablement (London: Intermediate Technology Publications Ltd., 1995) and Henry Sanoff, "Multiple Views on Participatory Design," International Journal of Architectural Research 2, no. 1 (2007): 57-69.

15 Sanoff, "Multiple Views," 59.

16 Hamdi, Housing Without Houses, 86.

17 Nabeel Hamdi and Reinhard Goethert, Action Planning for Cities: A Guide to Community Practice (Chichester, UK: John Wiley, 1997).

18 DiSalvo, Adversarial Design, 8.
As used in projects that apply design to politics, it emphasizes techniques of merging form and content in aesthetically compelling and functionally appropriate ways to support the means of governance-the mechanisms by which a state, organization, or group is held together. ${ }^{18}$ 
The focus on governance, although significant and important for the operationalization of collaborative planning in the field of urban development and in applying design thinking to improve accountability and transparency of government authorities, has been criticized for not problematizing in a deeper sense issues related to power and scales. The focus on consensus building, negotiation, and conflict resolution pays little attention to issues of diversity and power. The need for a collective intent in processes of participatory design (to strengthen social mobilization and to reach agreements within the timeframe of planning processes) has often resulted in the advancement of the issues where accords were reached. However, such agreements often have a more palliative and immediate nature, articulated by more prominent and visible voices, and they leave aside the contradictions, marginal perspectives, and structural issues associated with processes of urbanization. Therefore, processes and products of participatory design have encountered a series of challenges in trying to go beyond the local scale of the so-called "community" or neighborhood.

A fourth trend in participatory design has emerged as a response-not as a methodology for planners and architects of governmental authorities or development agencies to mediate diverse interests, but rather as a practice of social mobilization and contestation of the mode of production of the city. Participatory design is here concerned with the construction of new meanings associated with the social production of space. From this perspective, participatory design draws from critical urban theory literature, where participatory spatial practices are approached as a means to critically engage with the mode of production of the city and to unleash new spatial imaginaries. ${ }^{19}$

Henri Lefebvre's writings articulate the importance of thinking about space in contesting the reproduction of the contemporary city, where market-driven hegemonic structures have conditioned all areas of social life, including the ability to envision alternative futures..$^{20}$ Thus, conflicts over differing spatial imaginaries in the city have been a key form of contestation in urban areas, where critical urban theorists call for visions based on the values of "city for people, and not for profit." ${ }^{21}$ Within such a context, spatial imaginaries are seen as a mechanism to encourage utopian thinking, which is defined by John Friedmann as:

the capacity to imagine a future that departs significantly from what we know to be a general condition in the present. It is a way of breaking through the barriers of convention into a sphere of the imagination where many things beyond our everyday experience become feasible. All of us have this ability, which is inherent in human nature, Profit: Critical Urban Theory and the Right to the City (Abingdon, UK: Routledge, 2012). 
because human beings are insufficiently programmed for the future. We need a constructive imagination that we can variously use for creating fictive worlds. ${ }^{22}$

In the discipline of design, similar debates have emerged, where the concept and practice of participatory design is positioned in an agonistic definition of democracy. DiSalvo makes the distinction between "design for politics" and "political design," noting that the latter creates new spaces and themes for contestations and for revealing and confronting power relations while fostering new trajectories for action. "With this notion of revealing and contest," he says, "we can begin to consider political design as a kind of inquiry into the political condition. That is, whereas design for politics strives to provide solutions to given problems within given contexts, political design strives to articulate the elements that are constitutive of social conditions." ${ }^{23}$ Referring to DiSalvo, Björg vinsson et al. draws on the work of Chantal Mouffe to define agonistic participatory design as:

...alternative ways to organise future making and milieus for innovation that are more democratically oriented than traditional milieus that focus on expert groups and individuals. It also means moving away from the dominating technocratic and market-oriented view of innovation; a move towards practices where differences and controversies are allowed to exist, and dilemmas are raised and possibilities explored. The design researcher role becomes one of infrastructuring agonistic public spaces mainly by facilitating the careful building of arenas consisting of heterogeneous participants, legitimising those marginalised, maintaining network constellations, and leaving behind repertoires of how to organise socio-materially when conducting innovative transformations. ${ }^{24}$

\section{The Tensions of Participatory Design in Informal Settlement Upgrading}

The ASF-UK Change by Design workshops generated experiences that responded to the trends identified. However, while reflecting about these trends, a series of tensions emerged in the concept and practice of participation in design in processes of informal settlement upgrading.

First, from our experiences, we realized that practices of

22 John Friedmann, "The Good City: In Defense of Utopian Thinking," International Journal of Urban and Regional Research 24, no. 2 (2000): 463.

23 DiSalvo, "Design, Democracy and Agonistic Pluralism," 5.

24 Björgvinsson et al., "Agonistic Participatory Design," 1443. participatory design have tried in different ways to articulate the tension between the physical and social aspects of participation. Some have put more emphasis on physical production, often reducing participation to mere processes of consultation. Others have neglected the spatial product and morphological aspects of 
informal settlement upgrading, prioritizing the consolidation of community organizations, social mobilization, institutionalization of change, and policy implications of participation.

The second tension identified by the team has been the challenge for participatory design to engage with issues of social diversity and asymmetries of power. Although often motivated by concerns of recognition and empowerment, participatory design has faced challenges in recognizing social diversity without homogenizing needs and aspirations, while also proposing viable collective actions. Meanwhile, efforts focused on diversity have often been criticized for treating difference from an essentialist perspective, creating initiatives that target people from certain labelled "vulnerable" identities, rather than challenging the relations that cause exploitation. As a result, such practices could end up fragmenting communities and weakening social mobilizations, rather than achieving the desired empowerment outcomes..$^{25}$ Therefore, practitioners in participatory processes have often been short-sighted regarding issues of diversity of power because of the challenges imposed both by complex sets of social relations shaped by various asymmetries of power, and by donors' demand for measurable and product-driven outputs in short timeframes for activities. ${ }^{26}$

The third tension in the field of participatory design in informal settlement upgrading has to do with the issue of scale. Although participatory design practitioners recognize the need to engage in more nuanced ways with the relationship between localities and city-wide processes, only a few examples reveal actual engagement with such issues beyond the discourse of "replicability." City-wide thinking when introduced in processes of participatory design often merely sets the scene or context, and we rarely see such processes taking a more propositional position in addressing city-wide and structural concerns, breaking away from the threat of "NIMBYism" and isolated interventions. As a result, we observe that participatory design initiatives based on a "problem-solving" and "consensus building" approach have focused too much on the "low-hanging fruits" of urban conflicts, bringing to the forefront negotiations on issues that could be resolved in the short-term at the locality while failing to take on the challenges of facilitating a process that questions the underlying issues causing inequalities and injustices in cities. Meanwhile, participatory engagements motivated by the long-term battle of challenging the drivers of social injustices in the city encounter the challenges of

25 See Joy Moncrieffe and Rosalind Eyben, eds., The Power of Labelling: How People Are Categorized and Why It Matters (London: Earthscan, 2007).

26 See Bill Cooke and Uma Kothari, eds., Participation: The New Tyranny? (London: Zed Books, 2001). reconciling that struggle with meeting the immediate needs of the urban poor, leaving such needs unaddressed in the short-term.

The fourth tension in the practice of participatory design concerns issues of time. Paradoxically, participatory design initiatives are often concerned with the elaboration of an agreed on and 
27 Hamdi, Housing Without Houses, 107.

28 For more on the methodology of the workshops, see Alexandre Apsan Frediani, Matthew Anthony French, and Isis Nuñez Ferrera, Change by Design: Building Communities Through Participatory Design (Napier, NZ: Urban Culture Press, 2011); and Alexandre Apsan Frediani, Beatrice De Carli, Isis Nuñez Ferrera, and Naomi Shinkins, Change by Design: New Spatial Imaginations for Los Pinos (Oxford: Architecture Sans FrontièresUK, 2013). finite project. When "incrementalism" is included in participatory plans, it is within pre-defined concerns of what can and should be the end product. Therefore, the practice of participation is bounded by the length of the project-cycle. In this context, the challenge of participatory design has been to produce spaces that are adaptable and open-ended, unleashing alternatives that respond to changing needs and aspirations over time. Hamdi articulates the concept of "architecture of possibilities," ${ }^{27}$ but participatory design methodologies have rarely been able to incorporate such preoccupations in practice.

\section{The Contributions to Participatory Design}

With such trends and tensions in mind and with the motivation to rethink participatory design as a critical spatial practice, a series of workshops was organized by Architecture Sans Frontières-UK, titled Change by Design. Workshops in Salvador da Bahia, Brazil (2009 and 2010); Nairobi, Kenya (2011); and Quito, Ecuador (2013) consisted of two weeks of activ-ities in close collaboration with local partners; each workshop attracted, on average, 20 international participants from a variety of backgrounds.

During the workshop, participants are divided initially into groups according to three scales of design (dwelling, community, and city) and one cross-cutting theme (policy and planning). Activities are organized into four different stages: diagnosing, dreaming, developing, and defining. The groups work side by side in the first three stages, and in the fourth stage of the workshop, they come together to elaborate an activity to discuss a "portfolio of options." ${ }^{28}$

Each of these two-week workshops was planned in collaboration with local partners, and each one's strategic objectives were associated with particular contestations and concerns embedded in the local context. For example, in the case of Salvador, the partner the Movimento dos Sem Teto da Bahia (MSTB) - a homeless movement of Bahia-was at a stage of negotiations with the state government of Bahia when it was needed to demonstrate its abilities to plan and consolidate its occupations. The workshop worked as a demonstration of these abilities, supporting MSTB in both negotiating for solutions that were based on its own priorities and avoiding being incorporated into predefined housing programs perceived as unresponsive to the needs and aspirations of the urban poor. In the context of Nairobi, the Pamoja Trust, a nongovernmental organization (NGO), was keen to reflect on its participatory design approaches and strengthen its ability to disseminate them. The workshop was instrumental in its quest to influence and reshape government authorities in this process as it sought to contest the top-down approaches implemented through the Kenyan Slum Upgrading Programme (KENSUP). In Ecuador, 


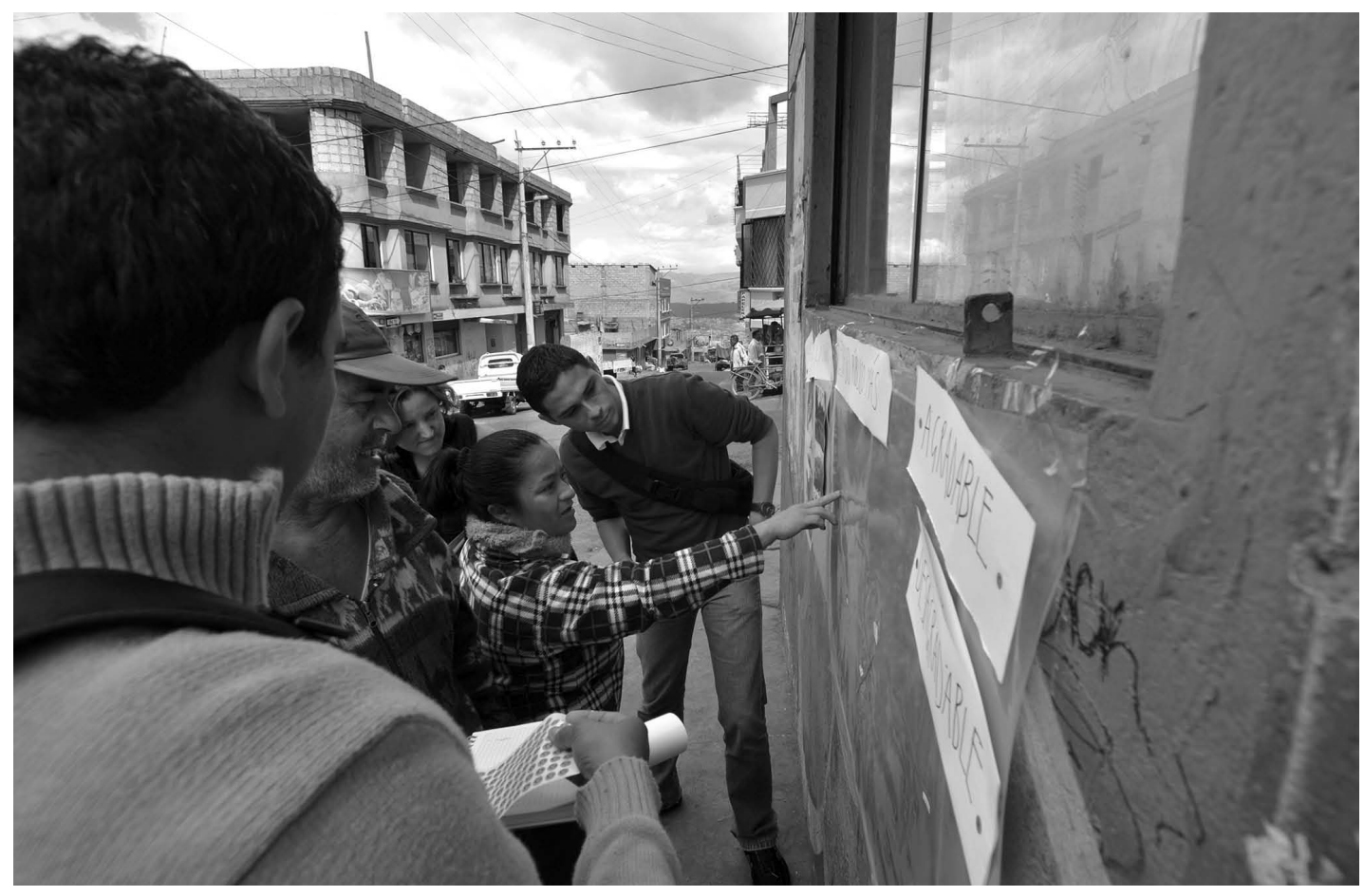

Figure 1

Mapping in Atucucho, Quito, Ecuador. This picture was taken during the ASF-UK Change by Design workshop, Imagining the Buen Vivir Neighbourhood through Participatory Design, which was held in August 2013 in Quito, Ecuador. Courtesy of ASF-UK.

29 COMBADE stands for Confederación Nacional de Barrios de Ecuador.

30 These principles also have been reflected in Alexandre Apsan Frediani and Camillo Boano, "Processes for Just Products: The Capability Space of Participatory Design," in The Capability Approach, Technology, and Design, ed. Ilse Oosterlaken and Jeroen van den Hoven (Dordrecht: Springer, 2012), 203-22.

31 For more on marginality as a site of resistance, see bell hooks, Yearnings: Race, Gender, and Cultural Politics (Boston: South End, 1990), 145-54. the partners from the National Confederation of Neighborhoods of Ecuador (CONBADE) ${ }^{29}$ and Universidad Politecnica Salesiana identified a major gap between a progressive development agenda based on the ideals of "Buen Vivir" (well living) and the capacity and interest of government actors to deliver them in the urban context. The workshop tried to contribute to ongoing efforts to set precedents of participatory approaches to informal settlement upgrading, illustrating how the "Buen Vivir" agenda could be applied to address urban challenges.

Through the experiences of participatory design embedded in these contestations, the workshops revealed three guiding principles that informed practice and reflection on the relationship between participation, design, and the social production of space: marginality as a position of resistance; solidarity through the recognition of difference; and alliance through multiplicity. ${ }^{30}$

First, the condition of marginality, analyzed for its expression in space, was deconstructed as the imposition of oppressive structures, but also as a potential locus of resistance, innovation, and imagination. ${ }^{31}$ Working together with collectives, groups, community organizations, and social movements and applying techniques of participatory action research, we analyzed processes of urbanization in relation to people's experience in space. Using participatory audio-visual techniques (e.g., mapping, photography, and participatory video), we tried to combine and integrate information about urban trends with the experiences of residents and their 


\begin{tabular}{|c|c|c|c|c|}
\hline \multicolumn{5}{|c|}{ Design Principles from Los Pinos, Municipality of Mejia, Ecuador } \\
\hline Integrated Principles & Dwelling & Community & City & Policy and Planning \\
\hline $\begin{array}{l}\text { Promote socially } \\
\text { inclusive processes }\end{array}$ & & & $\begin{array}{l}\text { Participation in the } \\
\text { environmental improve- } \\
\text { ment and protection of } \\
\text { natural resources. }\end{array}$ & $\begin{array}{l}\text { Adaptable processes } \\
\text { and product. }\end{array}$ \\
\hline $\begin{array}{l}\text { Build relationships } \\
\text { with external actors }\end{array}$ & & & $\begin{array}{l}\text { Reinforce existing } \\
\text { knowledge networks; } \\
\text { increase relations among } \\
\text { neighborhoods. }\end{array}$ & $\begin{array}{l}\text { Reinforce existing } \\
\text { networks. }\end{array}$ \\
\hline $\begin{array}{l}\text { Strengthen community } \\
\text { organization }\end{array}$ & & & & $\begin{array}{l}\text { Strengthen the organiza- } \\
\text { tional structures of the } \\
\text { community. }\end{array}$ \\
\hline $\begin{array}{l}\text { Inclusive design of the } \\
\text { built environment }\end{array}$ & $\begin{array}{l}\text { Respond to the cultural } \\
\text { diversity through multiple } \\
\text { housing typologies. }\end{array}$ & $\begin{array}{l}\text { Accessible design of the } \\
\text { neighborhood. }\end{array}$ & $\begin{array}{l}\text { Integrate urban and rural } \\
\text { agendas. }\end{array}$ & $\begin{array}{l}\text { Equitable spatial } \\
\text { opportunities. }\end{array}$ \\
\hline Right of permanence & & & $\begin{array}{l}\text { Stability in short and long } \\
\text { term in space. }\end{array}$ & Security of tenure. \\
\hline $\begin{array}{l}\text { Respond to } \\
\text { generational changes }\end{array}$ & $\begin{array}{l}\text { Provide the freedom to } \\
\text { expand and adapt accord- } \\
\text { ing to changing needs. }\end{array}$ & $\begin{array}{l}\text { Ability to maintain proxim- } \\
\text { ity to family and social } \\
\text { networks. }\end{array}$ & $\begin{array}{l}\text { Intergenerational } \\
\text { solidarity. }\end{array}$ & Intergenerational equity. \\
\hline Economic security & $\begin{array}{l}\text { Affordability in the short } \\
\text { and long term. }\end{array}$ & $\begin{array}{l}\text { Creation of economic } \\
\text { opportunities in } \\
\text { community spaces. }\end{array}$ & $\begin{array}{l}\text { Increase of income } \\
\text { generation opportunities. }\end{array}$ & $\begin{array}{l}\text { Integrated development; } \\
\text { secure and sustainable } \\
\text { provision of services. }\end{array}$ \\
\hline $\begin{array}{l}\text { Live according to one's } \\
\text { possibilities }\end{array}$ & & $\begin{array}{l}\text { Utilize available resources } \\
\text { in its full potential. }\end{array}$ & & $\begin{array}{l}\text { Strengthen community's } \\
\text { capacity to resist shocks, } \\
\text { stresses and trends. }\end{array}$ \\
\hline $\begin{array}{l}\text { Basic qualities for } \\
\text { dignified housing }\end{array}$ & $\begin{array}{l}\text { Allow the opportunity } \\
\text { for independent housing } \\
\text { environment; provide } \\
\text { quality and comfort for a } \\
\text { dignified way of living. }\end{array}$ & $\begin{array}{l}\text { Adequate response to } \\
\text { the conditions of the } \\
\text { locality; ability to maintain } \\
\text { proximity to family and } \\
\text { social networks. }\end{array}$ & & \\
\hline $\begin{array}{l}\text { Access to dignified } \\
\text { public services }\end{array}$ & & & $\begin{array}{l}\text { Equitable access to } \\
\text { the city. }\end{array}$ & $\begin{array}{l}\text { Dignified quality of spaces } \\
\text { and services. }\end{array}$ \\
\hline $\begin{array}{l}\text { Adequate balance } \\
\text { between rural and } \\
\text { urban lifestyles }\end{array}$ & $\begin{array}{l}\text { Provide an appropriate } \\
\text { balance between urban } \\
\text { and rural conditions. }\end{array}$ & $\begin{array}{l}\text { Appropriate balance } \\
\text { between urban and rural } \\
\text { conditions. }\end{array}$ & $\begin{array}{l}\text { Live in an urban-rural } \\
\text { area. }\end{array}$ & \\
\hline $\begin{array}{l}\text { Responsible } \\
\text { management of } \\
\text { natural resources }\end{array}$ & & $\begin{array}{l}\text { Sustainable design of } \\
\text { infrastructure and } \\
\text { neighborhood; equal } \\
\text { access to resources in } \\
\text { the community. } \\
\end{array}$ & $\begin{array}{l}\text { Inhabit an environment of } \\
\text { healthy life-style. }\end{array}$ & \\
\hline
\end{tabular}


everyday practices of appropriation of urban space. These processes aimed to redefine the problem, going beyond the immediate issues and events and trying to identify trends and structuring processes (see Figure 1).

In activities with individuals and groups, we also discussed dreams and aspirations. Here, the activities uncovered the values, principles, ideals, and utopias in relation to the home, neighborhood, and city in which this and future generations should live. In Salvador, the concept of "dignified housing" emerged as a catalyst theme; in Ecuador, residents spoke about the neighborhood of "Buen Vivir," referring to the 2013-2017 national plan of that name, which draws on indigenous definitions of "good living" that prioritizes values of equity, sustainability, harmony and solidarity over economic growth. Such concepts were useful in defining the spatial principles based on values and daily practices. These principles related not only to the process of design and construction but also to its spatial manifestations and meanings. (See Table 1 for examples of the design principles identified in the Ecuador workshop with the residents of Los Pinos, located in the municipality of Mejia, south of Quito. ${ }^{32}$ )

The second conceptual lens is related to understanding relations of solidarity through the recognition of difference. Inquiries into the production of space and utopias are addressed by revealing multiple perspectives, avoiding simple aggregations, and exploring how groups, in all of their complexity, live their urban experiences. Issues of identity are addressed in terms of social relations and inequalities, moving away from an essentialist interpretation of identities and diversity. Activities are carried out with specific groups, working with themes that address issues of gender relations, age, ethnicity, and religion in an intersectional way. Space (in terms of the home, neighborhood, and city) is used as a means to explore and unravel these diversities and inequalities in urban experiences.

In this approach, we follow the thinking of hooks, who argues that solidarity is more deeply formed when sharing and discussing differences-when bonds are formed not by identities or histories of oppression in common, but by hope for what is yet to come. Hooks inspires us when she argues that solidarity is a way not only to confirm defined identities, but to question them and open them for reconfiguration. Hooks calls for the rejection of particularism that fragments as much as the rejection of universalism that homogenizes. ${ }^{33}$

For us, in the participatory design process this perspective

32 Compiled from Frediani et al., "Change by Design: New Spatial Imaginations," 88-89.

33 See bell hooks, Yearnings: Race, Gender, and Cultural Politics (Boston: South End, 1990), 145-54. means working with difference progressively, first revealing concerns and... aspirations through personal interviews (or conversations), using drawings and forms of inquiry that are open and subjective. Then, with groups (e.g., children, adults, women, etc.), 


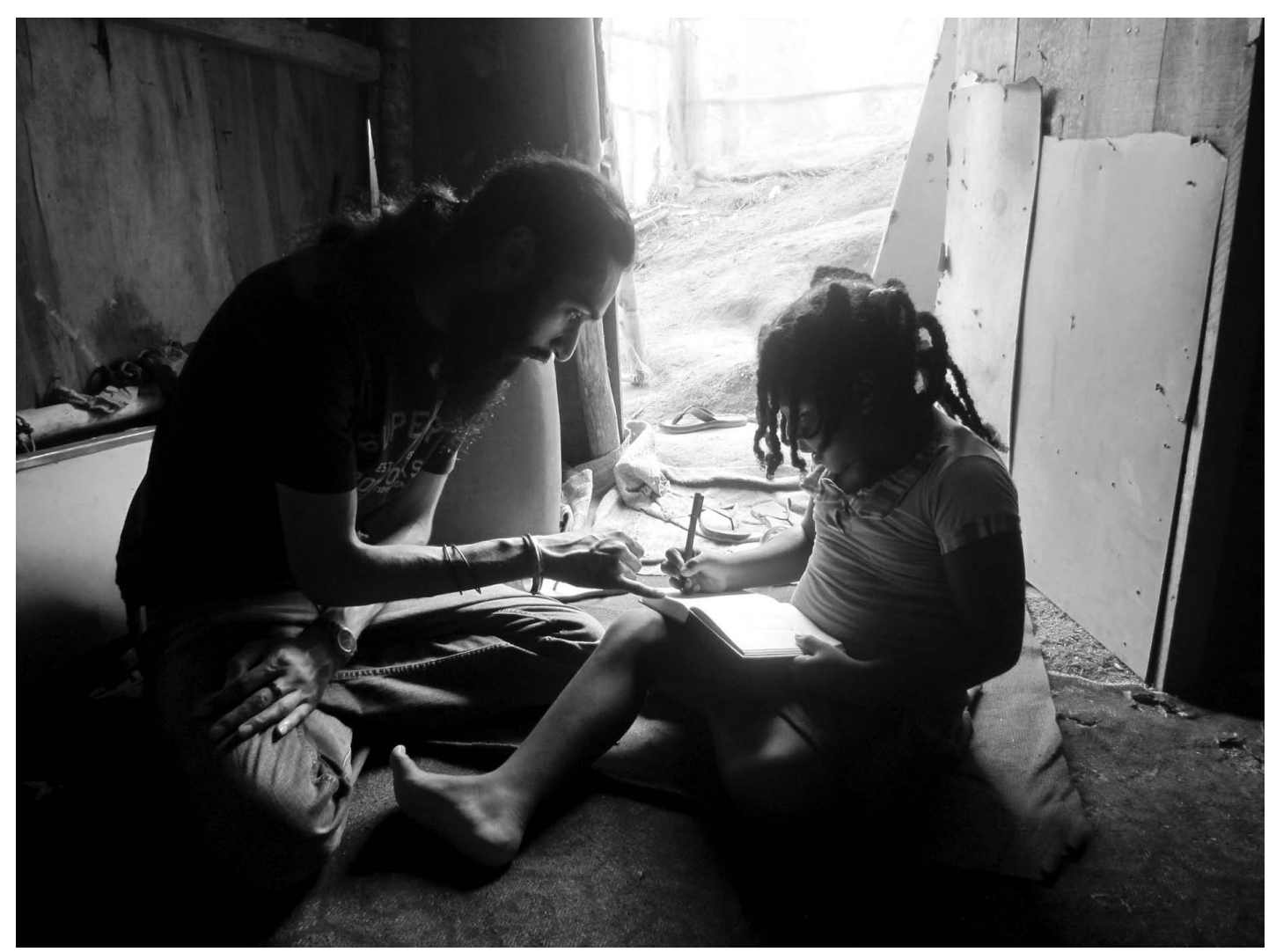

Figure 2

Interviews through Drawings in Paraiso, Salvador, Brazil. This picture was taken during the ASF-UK Change by Design, Building Communities through Participatory Design, which was held in April 2010 in Salvador, Brazil. Courtesy of ASF-UK.
34 Markus Miesse...n, The Nightmare of Participation (Berlin: Sternberg, 2010). we examine both the existing and the desired environment as a means to uncover values and motivations related to spatial production. We seek connections and differences, but within spaces of trust. This systematization of information reveals differences and similarities, fostering affinities (see Figure 2).

The third conceptual area informing our practice of participatory design is based on the idea of alliances through multiplicity. Here, we relate to Markus Miessen's book, The Nightmare of Participation, in which he critiques consensus-building approaches to participation and develops the concept of "conflictual participation," which combines participatory design with concepts from radical democracy. ${ }^{34}$ In his work "conflict" becomes the topic and space for dialogue - a means of bringing differences to the surface and thus influencing the sphere of power of what is designed and viable. According to Miessen and Basar:

The future spatial practitioner could arguably be understood as an outsider who, instead of trying to set up or sustain common denominators of consensus, enters existing situations or projects by deliberately instigating conflicts between often-delineated fields of knowledge. In this context, the spatial practitioner is presented as an enabler, a facilitator of interaction that stimulates alternative debates and speculations. Through the act of 
confronting the world with a re-reading of existing realities, these practitioners are doing what Hans Ulrich Obrist calls the "breaking of the consensus-machine." ${ }^{35}$

Referring to Derrida, Miessen works with the concept of "friendly enemies": those who "agree with the ethnic-political principles that inform the political association, but... disagree about the interpretation of these principles." ${ }^{\prime 36}$

We deal with these concerns with "consensus" by using spatial principles as ethnic-political alliances, and we have learned that their spatial manifestations can take different forms and can be implemented in different ways..$^{37}$ Therefore, we work with the idea of generating a "portfolio of options" based on the analysis of the various conditions and the multiple spatial appropriations and imaginations. This activity is conducted in the workshops as an open-ended game, in which the various options for interventions in space are discussed and the work of each of the four groups (dwelling, community, city and policy and planning) is integrated. This activity facilitates a discussion on the multiple ways of materializing design principles, reflecting on the different ways that space can be produced and building on and responding to principles identified through previous stages of the participatory design process. Negotiations are also prompted by information produced through other exercises, interviews, and policy analysis. In some cases, as in Salvador, we involved technicians working for government authorities, who contributed with key information in the discussions on spatial alternatives. In these events, we saw the importance of thinking about how space interconnects the various scales: connecting the private spaces of the house with more public concerns; connecting personal life with the urbanization processes; and connecting practices of self-help with policies and planning regulations.

This focus of the Change by Design methodology, in open-

35 Markus Miessen and Shumon Basar, Did Someone Say Participate? An Atlas of Spatial Practice (Frankfurt am Main: Revolver, 2006), 24-25.

36 Miessen, The Nightmare of Participation, 102.

37 For further reflections addressing limitations of consensus building in participatory design initiatives in informal settlements, see Camillo Boano and Emily Kelling, "Towards an Architecture of Dissensus: Participatory Urbanism in South-East Asia," Footprint 13 (2013): 41-62.

38 Carl DiSalvo, "Design and the Construction of the Publics," Design Issues 25, no. 1 (Winter 2009): 48-63.

39 Ibid., 52.

40 Ibid., 53. ing up possibilities, potential scenarios, and trade-offs, relates closely with DiSalvo's "tactics of projection." ${ }^{\prime 38}$ Instead of being driven by projections of what "should happen," DiSalvo argues that the tactics of projection are an "advanced indication of what might be, informed by knowledge of the past and present, and rendered by means of a skilled supposition of how the 'yet to come' might occur and to what effect." ${ }^{\prime 39}$ Thus, projection is about using design to outline potential courses of action, "articulating the range and complexity of possible consequences in an accessible and compelling manner." ${ }^{\prime 40}$

Furthermore, the "portfolio of options" is approached not as a mediation or resolution of conflicts, but as a mechanism to discuss trade-offs, priorities, differences, and values (see Figure 3). 


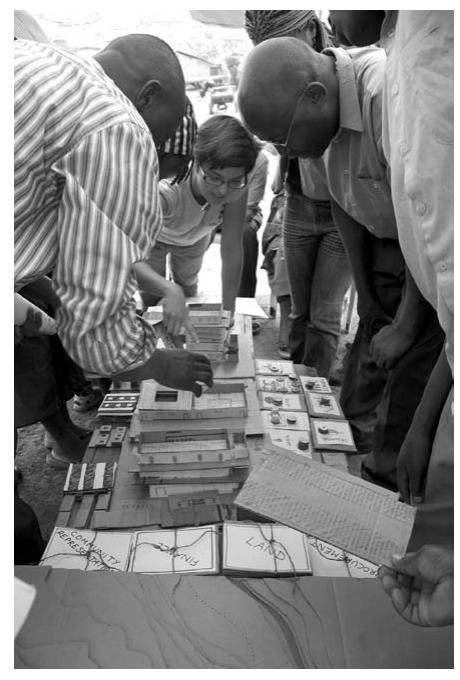

Figure 3

Portfolio of Options Exercise in Mashimoni, Nairobi, Kenya. This picture was taken during the ASF-UK Change by Design workshop, Building Communities through Participatory Design, which was held in June 2011 in Nairobi, Kenya. Courtesy of ASF-UK
41 Jeremy Till, "The Negotiation of Hope," in Architecture and Participation, ed. Peter Blundell Jones, Doine Petrescu, and Jeremy Till (London: Spon Press, 2005), 23-41.

42 John Forester, "Designing: Making Sense Together in Practical Conversations," Journal of Architectural Education 38, no. 3 (1985): 14-20.
This perspective resonates with Till's reflections on transformative participation, ${ }^{41}$ particularly when he quotes John Forester to argue that design should move away from a problem-solving approach toward one that focuses on a process of making sense of realities: "If form-giving is understood more deeply as an activity of making sense together, designing may then be situated in a social world where meaning, though often multiple, ambiguous, and conflicting, is nevertheless a perpetual practical accomplishment." ${ }^{\prime \prime 2}$

\section{Conclusion}

Thinking about these tensions in and conceptual lenses for participatory design, we see an opportunity to engage with a collective project of redefining the concept and practice of "participatory design" in the context of informal settlement upgrading. We hope to move away from the understanding of participatory design as a tool of conflict resolution and a way of merely mediating diverse set of interests, and toward a conceptualization that interrogates it as a practice of learning and action concerned with the production of a more just city. The experience of the ASF-UK Change by Design workshops tells us that, to re-imagine our cities, we need to reimagine the purpose and process of design. Participatory design is here seen as a practice that critically reflects on the current mode of production of the city, motivated to address inequalities and unlock aspirations for and imaginations of a future built on values of solidarity and recognition. This article hopes to contribute to the re-imagining of participatory design for informal settlement upgrading in a manner that can be understood and applied to instigate, provoke, imagine, and transform cities into more just ones.

Alexandre Apsan Frediani is lecturer and co-director of MSc Social Development Practice at the Bartlett Development Planning Unit, University College London (UCL). 